\title{
CEREBRAL SINUS VENOUS THROMBOSIS PADA PENDERITA SYSTEMIC LUPUS ERYTHEMATOSUS
}

\author{
CEREBRAL SINUS VENOUS THROMBOSIS IN SYSTEMIC LUPUS \\ ERYTHEMATOSUS PATIENT \\ Destika Fahrina, * Mohammad Arief Rachman Kemal, **Adiel Amaris Syah, ** Melita, ${ }^{* *}$ Lyna Soertidewi**
}

\begin{abstract}
Cerebral sinus venous thrombosis (CSVT) may sometimes be associated with autoimmune disorder like systemic lupus erythematosus (SLE). It is characterized by dural venous thrombosis which can cause variety of symptoms including headache, convulsion, motor weakness, and decreased level of consciousness. Thrombosis often occurs in the lower extremities in postpartum women due to prolonged bed rest and caesarean section. We reported a 33-year-old woman, who presented with chief complaint of weakness in the left arm and leg, a history of headache and seizures, the following 3 weeks, she had swelling and pain which started at the tip of the left foot then right leg and to the waist. D-dimer level was increased with positive ANA test. Diagnostic investigations include non-contrast head CT scan, CTV, DSA, Doppler ultrasound and thoracoabdominal vasculare CT. Low molecular weight heparin (LMWH) was given for 5 days, continued with oral anticoagulant.
\end{abstract}

Keywords: Cerebral sinus venous thrombosis, deep vein thrombosis, LMWH, postpartum, systemic lupus erythematosus

\begin{abstract}
ABSTRAK
Cerebral sinus venous thrombosis (CSVT) dapat berkaitan dengan gangguan autoimun seperti systemic lupus erythematosus (SLE). Hal ini ditandai adanya trombosis vena dural yang menyebabkan berbagai gejala, seperti nyeri kepala, kejang, kelemahan motorik, serta penurunan kesadaran. Trombosis juga sering terjadi di ekstremitas bawah pada perempuan postpartum akibat tirah baring yang lama dan tindakan seksio sesaria. Dilaporkan kasus seorang perempuan 33 tahun dengan keluhan kelemahan tubuh sisi kiri serta riwayat nyeri kepala dan kejang yang 3 minggu kemudian dijumpai bengkak dan nyeri mulai dari ujung kaki kiri kemudian kaki kanan, hingga naik sampai pinggang. Terdapat peningkatan D-dimer dengan tes ANA (+). Pemeriksaan penunjang diagnostik berupa head CT scan nonkontras, CTV, DSA, USG doppler ekstremitas serta CT vascular thoracoabdominal. Pasien diberikan terapi low molecular weight heparin (LMWH) selama 5 hari, dilanjutkan dengan antikoagulan oral.

Kata kunci: Cerebral sinus venous thrombosis, deep vein thrombosis, LMWH, postpartum, systemic lupus erythematosus

*Departemen Neurologi FK USU/RSUP H. Adam Malik, Medan; **RS Pusat Otak Nasional, Jakarta. Korespondensi: dr.destika@ yahoo.com.
\end{abstract}

\section{PENDAHULUAN}

Cerebral sinus venous thrombosis (CSVT) telah dikenal sejak abad ke-19, namun diagnosisnya masih sering terlupakan karena gambaran klinis yang bervariasi. Kejadiannya lebih sering terjadi pada perempuan dibandingkan pria $(3: 1) .^{1-3}$

Hiperkoagulabilitas berperan penting sebagai penyebab CSVT pada perempuan hamil dan pasca melahirkan. Perubahan sistem koagulasi ini terjadi pada trimester ketiga. Adanya trauma dan kehilangan cairan selama melahirkan akan memperburuk status hiperkoagulabilitas dan menyebabkan stasis vena akibat tirah baring yang lama. Prosedur melahirkan secara seksio sesaria juga menjadi pemicu terjadinya trombosis. ${ }^{1-2,4}$
Cerebral sinus venous thrombosis dapat berhubungan dengan penyakit autoimun seperti systemic lupus erythematosus (SLE), walaupun jarang (sekitar 0,36\%) dan lebih rendah dibandingkan CSVT pada Behcet disease. Pemeriksaan antiphospholipid antibody (APLA) dan lupus anticoagulant (LA) menunjukkan hasil yang positif. ${ }^{5-7}$

\section{KASUS}

Seorang perempuan berusia 33 tahun datang dengan keluhan kelemahan lengan dan tungkai kiri secara tiba-tiba 1 hari sebelum masuk RS. Gejala dimulai sejak 1 minggu sebelumnya berupa nyeri kepala berdenyut di sebelah kanan, hilang timbul. Pada 1 hari sebelum masuk rumah sakit, pasien mengalami kejang berupa menyentak di seluruh 

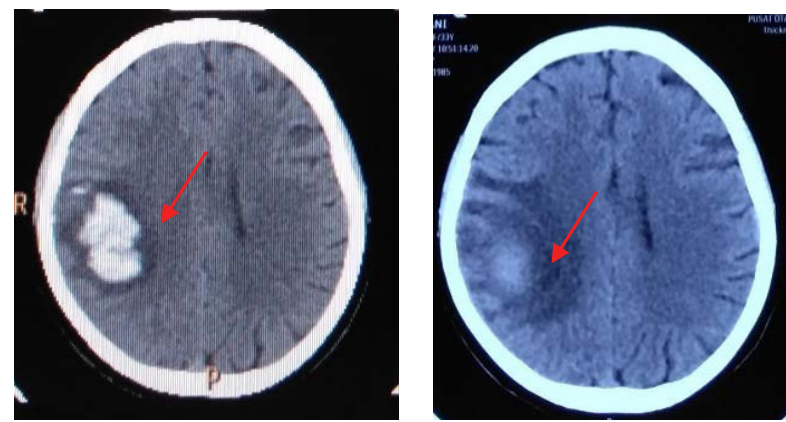

Gambar 1. Tampak Perdarahan pada CT Scan Awal (a) yang Menjadi Lebih Teresorpsi 1 Bulan Kemudian (b)
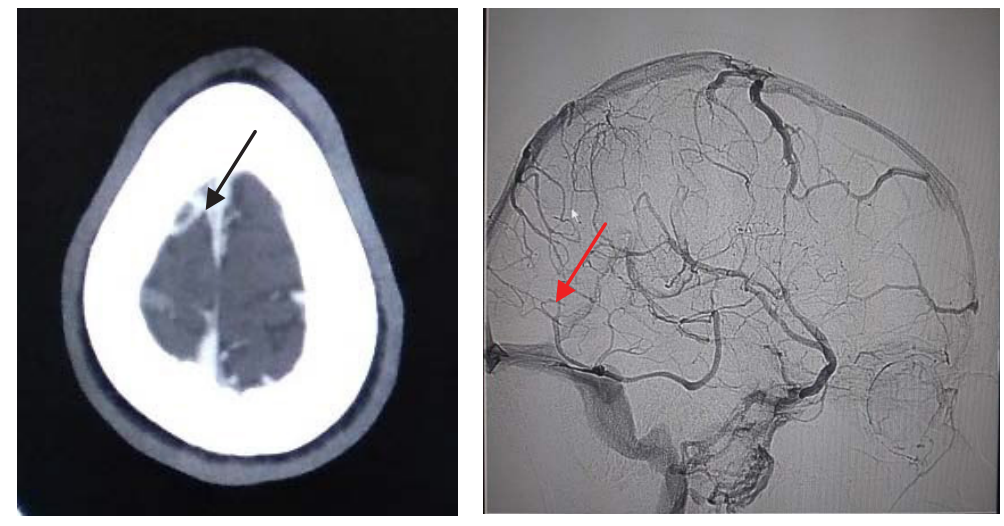

Gambar 2. CT Venography (a) dan Digital Subtraction Angiography (b)

tubuh, durasi \pm 10 menit, frekuensi $1 \mathrm{x}$, sebelum kejang pasien sadar, saat kejang pasien tidak sadar dan setelah kejang pasien tertidur tiga minggu kemudian, terdapat nyeri dan bengkak mulai dari ujung kaki sebelah kiri kemudian ke sebelah kanan, naik ke ekstremitas hingga pinggang. Pasien baru saja melahirkan anak ketiga 1 minggu yang lalu melalui operasi seksio sesaria. Tidak ditemukan riwayat hipertensi dalam kehamilan sebelumnya dan penggunaan kontrasepsi oral. Pasien juga tidak pernah mengeluhkan bercak merah pada wajah serta nyeri pada persendian. Riwayat merokok disangkal.

Pada pemeriksaan fisik didapatkan pasien sadar, hemiparesis sinistra dengan kekuatan motorik sisi kiri 2, refleks fisiologis normal, refleks Babinski (+) sinistra, disertai bengkak dan nyeri warna kemerahan dan hangat di kedua ekstremitas sampai pinggang. Pemeriksaan funduskopi dan lain-lain

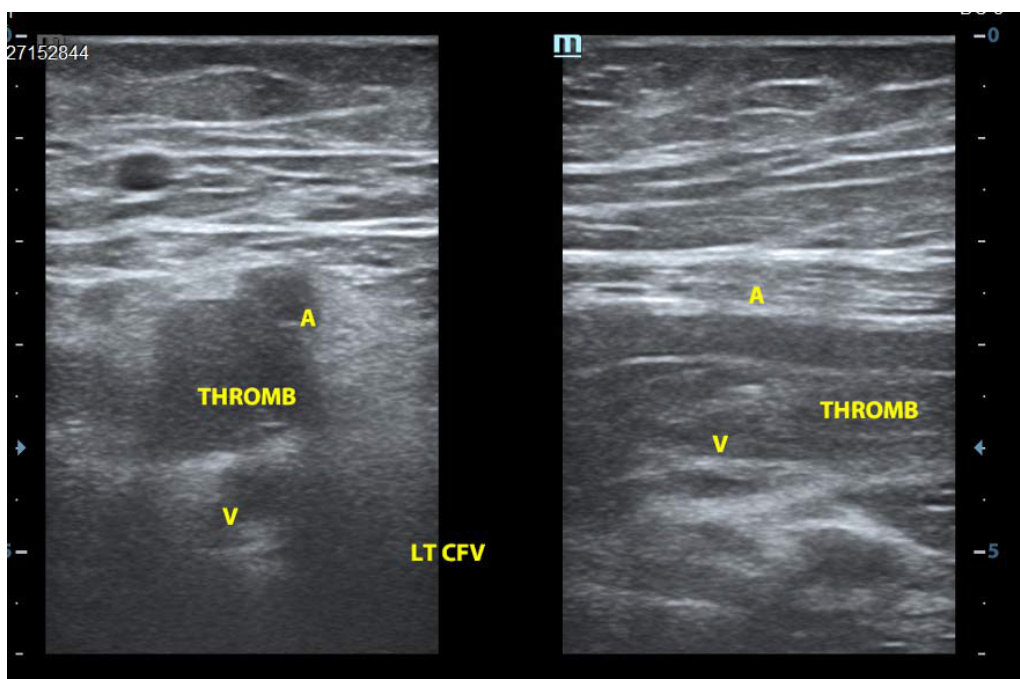

Gambar 3. USG Doppler Ekstremitas (27/07/2018) 


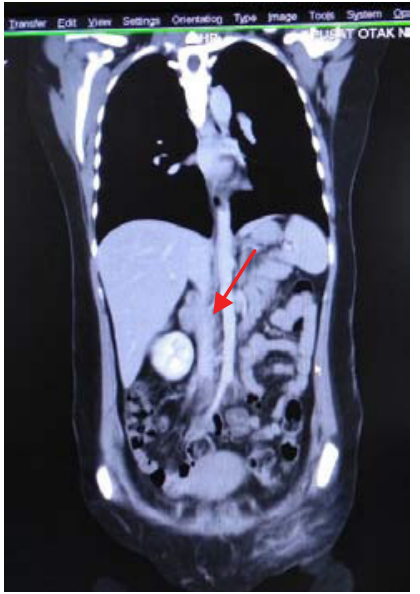

Gambar 6. CT Vasculare Torakoabdominal

dalam batas normal.

Pemeriksaan darah menunjukkan peningkatan kadar D-dimer $(7440 \mathrm{ng} / \mathrm{mL})$, ANA $(+)$ dan $(s m+)$ (anti-smith antibodies yang muncul pada SLE). Adapun kadar antitrombin III, protein $\mathrm{C}$, dan protein $\mathrm{S}$ dalam batas normal.

Pada CT scan kepala tampak perdarahan subakut ringan dengan edema perifokal di lobus frontal kanan yang berkurang dalam 1 bulan pemantauan (Gambar 1a dan b). Dilakukan pemeriksaan CT venography yang menunjukkan dilatasi vena yang tidak terisi kontras penuh pada fase vena kortikal di lobus frontal kanan dengan sangkaan trombosis. Oleh karena itu, pasien dilakukan pemeriksaan digital subtraction angiography (DSA) dan dijumpai adanya delayed filling sinus transversus kiri, suspek venous thrombosis (Gambar 2a dan b).

Hasil USG Doppler ekstremitas (Gambar 3) sesuai dengan gambaran deep vein thrombosis (DVT). Pemeriksaan computed tomography vasculare/CTV thoracoabdominal, tampak trombus di vena kava inferior setinggi korpus L4, vena iliaka komunis kanan kiri, vena iliaka interna eksterna kanan kiri, vena superfisial profunda kiri (Gambar 4), sugestif trombus akut vena femoralis komunis kanan, vena superfisial profunda kiri.

Pasien diberikan enoxaparin sodium selama lima hari dilanjutkan dengan antikoagulan oral (natrium warfarin/simarc) selama 3-12 bulan (guideline of anticoagulant, dengan INR 2,0-3,0) fisioterapi dan stocking compression dilakukan agar pasien dapat mobilisasi dan mengurangi edema.

\section{PEMBAHASAN}

Cerebral sinus venous thrombosis pada pasien ini diawali dengan keluhan nyeri kepala diikuti lemah lengan dan tungkai kiri serta kejang yang 3 minggu kemudian dijumpai bengkak dan nyeri mulai dari ujung kaki kiri kemudian kaki kanan, hingga naik sampai pinggang. Terdapat peningkatan D-dimer dengan tes ANA (+). Pemeriksaan penunjang diagnostik berupa head $\mathrm{CT}$ scan nonkontras (perdarahan intraparenkim volume 10,7cc dengan edema di sekitarnya dan gambaran vena kortikal yang melebar di lobus frontal), CTV (dilatasi vena yang tidak terisi kontras penuh di lobus fontal kanan, dengan sangkaan trombosis), DSA (delayed filling sinus transversus kiri dengan sangkaan trombosis vena), USG doppler ekstremitas (sesuai gambaran DVT) serta CTV thoracoabdominal (trombus di vena cava inferior setinggi korpus L4, vena iliaka komunis kanan kiri, vena iliaka interna eksterna kanan kiri, vena superfisial profunda kiri. Sugestif akut trombus vena femoralis komunis kanan, vena superfisial profunda kiri. Sistem thoracoabdominal dalam batas normal. Cerebral sinus venous thrombosis yang dialami penderita terjadi 1 hari setelah melahirkan secara seksio saesaria. Angka kejadian CSVT pada perempuan postpartum sekitar $0,012 \%$ dan $15 \%$ kasus muncul dalam 48 jam pertama setelah melahirkan. Cerebral venous sinus thrombosis lebih sering terjadi pada perempuan dibandingkan pria dengan rasio $3: 1 .^{1,4,8-12}$

Kehamilan dan masa nifas merupakan penyebab tromboemboli vena. Beberapa perubahan fisiologi sistem koagulasi memengaruhi status protrombosis terutama pada trimester ketiga dan menyebabkan status hiperkoagulasi. Dehidrasi yang terjadi akibat kehilangan darah dan trauma lokal selama melahirkan dapat menyebabkan perubahan status protrombosis. Hiperkoagulabilitas dan stasis vena dapat terjadi akibat tirah baring yang lama, terutama setelah melahirkan secara seksio sesaria yang akhirnya menyebabkan trombosis. Oklusi vena serebral memicu terjadinya edema sitotoksik dan vasogenik, sedangkan oklusi dari sinus menyebabkan hipertensi intrakranial. ${ }^{1,4,8-12}$ 
Cerebral sinus venous thrombosis mungkin disebabkan oleh kerusakan sinus venosus selama melahirkan, akibat sekunder dari fluktuasi peningkatan tekanan intrakranial. Gejala ini biasanya timbul 3 minggu setelah melahirkan dengan manifestasi klinis nyeri kepala. Salah satu penelitian menyatakan bahwa risiko CSVT postpartum meningkat seiring dengan peningkatan umur ibu, peningkatan lama rawatan rumah sakit, melahirkan secara seksio sesaria, serta hipertensi, infeksi, dan muntah yang berlebihan selama kehamilan. ${ }^{11-12}$ Seksio sesaria meningkatkan risiko CSVT karena penurunan protein $\mathrm{C}$ yang menyebabkan kerusakan jaringan dan memicu terjadinya pembekuan darah dengan peningkatan pembentukan trombin. ${ }^{1-2}$

Perempuan hamil dan postpartum memiliki risiko 4-5 kali menderita tromboemboli vena. Riwayat trombosis sebelumnya, trombofilia baik bawaan maupun didapat, usia di atas 35 tahun, serta penggunaan kontrasepsi oral meningkatkan risiko tromboemboli vena. ${ }^{13-16}$

Beberapa mekanisme berperan terhadap terjadinya CSVT pada SLE. Interaksi kompleks antara sel endotel dan LA akan memicu penghambatan terhadap protein $\mathrm{C}$ dan $\mathrm{S}$ yang bertanggung jawab terhadap terjadinya trombosis. Autoantibodi menyerang permukaan fosfolipid yang bermuatan negatif, sehingga memicu aktivasi platelet untuk membentuk trombus. Gangguan fibrinolisis, antitrombin III, hiperfibrinemia, atau perubahan koagulasi juga dapat menimbulkan trombosis. ${ }^{5-7}$

Cedera endotel juga berperan sebagai penyebab immune complex induced vasculitis yang akhirnya terjadi CSVT. Inflamasi dapat mengurangi aktivitas fibrinolitik melalui upregulation pembentukan plasminogen activator inhibitor (PAI). ${ }^{5-7}$

Merokok berhubungan dengan kejadian trombosis. Pasien bukan merupakan perokok aktif, namun merokok memicu cedera endotel sehingga endotelium teraktivasi dan menimbulkan trombosis. ${ }^{7}$ Merokok dalam waktu lama dapat menyebabkan peningkatan kadar fibrinogen, adhesi platelet, peningkatan viskositas darah dan penurunan aliran darah otak. ${ }^{17}$
Kelemahan lengan dan tungkai kiri, nyeri kepala, dan kejang yang dialami pasien kemungkinan karena perdarahan intraparenkim dengan volume $10,7 \mathrm{cc}$ dengan edema di sekeliling dan gambaran vena kortikal yang melebar di lobus frontal kanan. Manifestasi klinis dari CSVT tergantung dari lokasi trombosis. Keterlibatan kortikal dapat menyebabkan kelemahan motorik kontralateral. ${ }^{2-12}$

Dari 3 penelitian berbeda, nyeri kepala $(93,7 \%)$ merupakan gejala utama yang paling banyak ditemukan pada penderita CSVT diikuti dengan penurunan kesadaran $(90,6 \%)$, kejang $(75 \%)$, serta defisit neurologis fokal $(46,8 \%))^{2-3,11-12}$

Trombosis di dural vein menimbulkan manifestasi klinis seperti kejang, nyeri kepala, kehilangan kesadaran, dan lainnya. ${ }^{1-2}$ Trombosis di dural vein dapat menyebabkan pembentukan darah dalam sinus venosus otak yang mencegah darah mengalir ke otak. ${ }^{18}$ Beberapa gambaran klinis dapat membedakan CSVT dengan penyakit serebrovaskular lainnya. Kejang fokal atau kejang umum sering terjadi pada pasien CSVT (40\%). Beberapa gambaran klinis lain yang berhubungan dengan lokasi anatomi dari drainase vena serebral terjadi karena keterlibatan otak secara bilateral, tetapi sangat jarang dijumpai. ${ }^{2}$ Penggunaan obat antiepilepsi (tidak diberikan obat antiepilepsi dan belum dilakukan pemeriksaan EEG) pada pasien CSVT akut dengan lesi supratentorial dan kejang dapat mencegah serangan kejang yang berulang. ${ }^{19}$

Kebanyakan nyeri kepala pada SLE bersifat kronik, sedangkan nyeri kepala yang timbul pada CSVT umumnya bersifat akut dan subakut. ${ }^{6}$

Deep Vein Thrombosis merupakan bentuk DVT yang paling umum, sekitar 70-90\% mengenai vena ileo femoral kaki kiri. Angka kejadian tromboemboli vena sekitar 13/100.000 kehamilan, setengahnya terjadi setelah melahirkan. Perubahan status protrombotik setelah melahirkan sampai normal kembali memerlukan waktu hingga 6 minggu. Kebanyakan kasus terjadi dalam 4 minggu postpartum (95\%), dan angka kejadian minggu pertama postpartum sekitar (18\%). ${ }^{13-15}$ Deep Vein Thrombosis yang dialami pasien diawali dengan 
adanya bengkak, nyeri kemerahan dan pada perabaan dijumpai hangat pada kaki sebelah kiri, lalu kaki sebelah kanan dan naik sampai ke atas hingga pinggang.

Rudolf Virchow menyatakan bahwa ada 3 kondisi yang dapat mencetuskan trombus yaitu cedera endotel, stasis atau turbulensi aliran darah, dan hiperkoagulabilitas darah. Stasis dan cedera endotel menyebabkan DVT yang terjadi setelah trauma sedangkan hiperkoagulabilitas bertanggung jawab terhadap terjadinya DVT spontan. ${ }^{2-12}$

Ditemukan nyeri dan bengkak pada ekstremitas bawah sebelah kiri, 2 hari kemudian mengenai ekstremitas kanan bawah. Keterlibatan ekstremitas kiri bawah lebih sering terjadi (29\%) dibandingkan ekstremitas kanan bawah (16,66\%). Gejala utama yang sering ditemukan berupa edema tungkai $(85,71 \%)$ diikuti dengan ketidaknyamanan saat berjalan, nyeri, dan eritema. ${ }^{20}$

Pada pemeriksaan neurologis dijumpai refleks fisiologis yang normal dan dijumpai refleks patologis Babinski di ekstremitas inferior sinistra. Refleks patologis ini berhubungan dengan lokasi lesi dengan gambaran hyperdense di hemisfer kanan. ${ }^{2}$

Ditemukan gambaran funduskopi yang normal pada pasien ini. Menurut Singh dkk, tahun 2016, yang menyatakan bahwa hanya $33 \%$ pasien CSVT dengan SLE yang menunjukkan gambaran papiledema. Dekatnya anatomi dari lokasi lesi ke mata atau peningkatan tekanan intrakranial juga berhubungan dengan perubahan gambaran papil pemeriksaan funduskopi. ${ }^{5}$

D-dimer merupakan hasil degradasi fibrin. D-dimer memiliki spesifisitas yang rendah pada emboli paru namun kadarnya meningkat selama kehamilan, bahkan setelah melahirkan. Kadar D-dimer yang meningkat menggambarkan tingkat aktivasi sistem fibrinolisis dan koagulasi. Peningkatan D-dimer terjadi terutama pada trimester ketiga sehingga hal ini meningkatkan kecenderungan terjadinya tromboemboli vena. Pemeriksaan serial D-dimer hari 1, 3, dan 5 setelah seksio sesaria sebaiknya dilakukan untuk memprediksi terjadinya DVT. ${ }^{2,21-22}$
Kadar D-dimer yang positif ditemukan pada 34 dari 35 pasien yang menderita CSVT. Perluasan anatomis sinus trombosis mungkin berhubungan dengan kadar D-dimer. Namun kadar D-dimer yang normal juga dapat ditemukan pada penderita CSVT. Kadar D-dimer dapat menurun saat awitan serangan dan hal ini menunjukkan pada keadaan akut maupun kronik cenderung memiliki kadar D-dimer yang negatif., ${ }^{2,2}$

Tidak ditemukan abnormalitas pada pemeriksaan protein antikoagulan (protein $\mathrm{C}$ dan $\mathrm{S}$ serta anti trombin III). Perubahan koagulasi selama kehamilan dan postpartum meliputi penurunan protein $\mathrm{S}$, peningkatan protein $\mathrm{C}$, peningkatan fibrinogen, serta peningkatan faktor V dan VII. Penelitian menunjukkan bahwa dari 51 pasien CSVT, hanya sekitar $2 \%$ pasien yang mengalami defisiensi antitrombin III. Faktor risiko genetik CSVT lainnya meliputi faktor VLeyden homozygous mutation, anticardiolipin $(+)$ atau antibodi antifosfolipid $(+)$, atau homosisteinemia. ${ }^{2-3,12}$

Trombosis sistemik yang terjadi pada pasien ini diduga kuat berhubungan dengan SLE karena tidak ditemukan abnormalitas protein antikoagulan yang biasanya terjadi pada perempuan postpartum. Antinuclear antibodies merupakan tes yang memiliki spesifisitas yang tinggi dengan hasil yang positif pada $>95 \%$ pasien SLE. Namun pada pasien ini hanya satu organ saja yang terlibat dengan hasil tes ANA (+) sehingga dapat disebut sebagai silent lupus. Berdasarkan Systemic Lupus International Collaborating Clinics (SLICC) tahun 2012, diagnosis SLE pada pasien ini dapat ditegakkan karena ditemukan satu kriteria klinis berupa kejang dan satu kriteria imunologis berupa tes ANA $(+)^{7,23}$

Imejing yang digunakan untuk menegakkan diagnosis CSVT dapat berupa noninvasif (CT, MRI dan ultrasound) dan invasif (cerebral angiography, direct cerebral venography, perfusion imaging methods). ${ }^{2,14,12,24}$

Gambaran radiologi yang sering ditemukan pada CSVT adalah perdarahan $(84,3 \%)$ dan nonperdarahan $(15,7 \%)$. Computed tomography tanpa kontras sering menunjukkan gambaran normal, 
namun ada juga yang menunjukkan gambaran CSVT. Variasi dari gambaran anatomi sinus venosus menyebabkan peranan $\mathrm{CT}$ dalam mendiagnosis CSVT menjadi kurang sensitif. Gambaran CT scan kepala nonkontras yang abnormal hanya ditemukan pada $30 \%$ pasien. Tanda primer dari CSVT akut pada head CT scan nonkontras adalah lesi hyperdense yang mengisi vena atau sinus dural ( $1 / 3$ kasus). Trombosis pada bagian posterior dari sinus sagitalis superior dapat muncul.,12 (memang hasil head CT scan nonkontras dapat berupa perdarahan, namun pada pemeriksaan DSA dan CTV baru terbukti CSVT).

Computed tomography dan MRI bermanfaat dalam mengevaluasi pasien dengan CSVT. Namun diagnosis CSVT juga tidak dapat disingkirkan walaupun tidak ditemukan gambarannya pada MRI dan CT scan. Magnetic resonance venography atau computed tomography venography (MRV/ CTV) dapat dilakukan jika gambaran CT/MRI tidak mendukung ke arah CSVT. Computed tomography vasculare pada pasien ini menunjukkan gambaran dilatasi vena yang tidak terisi kontras penuh pada fase arteri maupun vena kortikal di lobus frontal kanan dengan sangkaan trombosis. Computed tomography venography lebih baik dilakukan pada awitan subakut maupun kronik karena densitas sinus trombosis yang bervariasi. Gambaran vena serebral dapat dilihat dari MRV, sedangkan gambaran sinus lebih baik dilihat melalui DSA. 2,12,24

Pada pemeriksaan DSA (untuk menegakkan CSVT, dengan sensitivitas $97-100 \%$ dan spesifisitas 98-99\%) ditemukan gambaran delayed filling sinus transversus kiri (susp thrombosis vein). Sinus sagitalis superior (62\%) merupakan sinus venosus yang paling banyak terkena diikuti dengan sinus transversus (41\%). Gambaran angiografi dapat berupa kegagalan munculnya sinus yang berhubungan dengan oklusi, kongesti vena dengan dilatasi kortikal, kulit kepala dan vena facial. Fase vena dari angiografi serebral akan menunjukkan gambaran filling defect cerebral venous thrombosis. Acute sinus dural dan cortical vein thrombosis dapat menyebabkan keterlambatan sirkulasi vena serebral. Normalnya, vena akan mulai opacify (tak tembus cahaya) pada detik ke 4 s/d 5, sistem vena serebral akan lengkap opacify pada menit ke $7 \mathrm{~s} / \mathrm{d} 8 .^{2-3,12}$

Diagnosis dini DVT dapat ditegakkan melalui pemeriksaan ultrasound yang memiliki sensitivitas 97-100\% dan spesifisitas 98-99\%. Sedangkan CT scan kontras dan MRI dapat menegakkan diagnosis trombosis pada $13 \%$ kasus. ${ }^{2,16,25}$

\section{Computed tomography vasculare} thoracoabdominal (CT vasculature abdomen digunakan untuk mengetahui fase arteri, fase vena dan fase delay sehingga bisa diketahui di fase mana terjadi gangguan vaskular) dilakukan karena ditemukan DVT bilateral naik sampai pinggang yang mendukung kecurigaan ke arah trombosis inferior vena cava (IVC). Sekitar 2,6\% s/d 4,0\% DVT pada tungkai bawah merupakan trombosis IVC. Computed tomographyvenography terkadang lebih dipilih dalam menegakkan trombosis IVC dibanding MRV karena sering ditemukan artefak ferromagnetic. 13,16,20,25 $^{2}$

Terapi medikamentosa yang digunakan pada pasien ini adalah enoxaparin sodium $2 \times 50 \mathrm{mg}$ diberikan selama 5 hari. Enoxaparin sodium merupakan golongan LMWH yang cenderung aman diberikan pada pasien postpartum karena tidak melewati plasenta, aman untuk ibu menyusui, risiko rendah mengalami heparin induced trombositopenia dan osteoporosis. Terapi antikoagulan ini diberikan selam 3-6 bulan. Terapi heparin (UFH atau LMWH) dapat dimulai bersamaan dengan warfarin. Pemberian LMWH minimal diberikan selama 5 hari dan dapat dihentikan apabila INR $>2,0$ pada 2 hari berikutnya. $^{2,12}$

Warfarin sodium (tersedia dari BPJS) diberikan 5 hari setelah penggunaan enoxaparin sodium. Pemberian warfarin sodium harus dilanjutkan hingga 3-12 bulan dengan mempertahankan INR 2,0-3,0 untuk mencegah CSVT berulang dan kejadian tromboemboli vena lainnya. ${ }^{2,19}$

Fisioterapi dilakukan untuk mobilisasi serta mencegah trombosis akibat tirah baring yang terlalu lama. Juga diberikan compressor stocking untuk mengurangi edema dan post-thrombotic syndrome. ${ }^{20,25}$

Prognosis pada pasien ini adalah dubia ad bonam. Dijumpai perbaikan skor National Institutes 
of Health Stroke Scale $(8 \rightarrow 4)$ dan Modified Rankin Scale (mRS) $(4 \rightarrow 2)$ saat keluar rumah sakit serta ditemukan perbaikan kekuatan motorik dari awal masuk $(2 \rightarrow 4)$. Perbaikan luaran mungkin disebabkan oleh oklusi yang terbatas dan muncul dari rekanalisasi yang cepat dengan terbentuknya kolateral., ${ }^{210}$

Berdasarkan 5 penelitian kohort ditemukan bahwa beberapa faktor yang berhubungan dengan prognosis yang buruk yaitu berdasarkan demografi (umur $>37$ tahun, jenis kelamin laki-laki), gejala klinis (koma, defisit neurologis, skor NIHSS buruk, penurunan kesadaran, hemiparese, kejang), neuroimaging (perdarahan intraserebral, keterlibatan straight sinus, trombosis deep venous sinus, infark vena), faktor risiko (kanker, infeksi SSP, koagulopati herediter). ${ }^{2}$

Complete recovery dapat ditemukan pada $79 \%$ pasien. Prognosis pasien ini adalah ragu-ragu menuju baik karena dijumpai perbaikan skor NIHSS (dari 8 menjadi 4), skor mRS (dari4 menjadi2) saat keluar dari rumah sakit, usai $<37$ tahun, perbaikan klinis pasien (bengkak, nyeri dan kemerahan sudah berkurang) serta gambaran radiologis. Pada sebuah penelitian prospektif ditemukan bahwa angka mortalitas sekitar 9,4\%. Mortalitas pada CSVT dengan SLE mencapai $30-50 \%$. Namun dengan neuroimajing dan LMWH, angka mortalitas berkurang menjadi $11,8 \%$. Perbaikan komplit atau parsial yang diamati pada pasien yang berhasil survive (76,5\%), tidak dijumpai relapse atau luaran yang buruk dengan defisit neurologis permanen selama 3 tahun follow up. ${ }^{6}$

\section{KESIMPULAN}

Cerebral sinus venous thrombosis ditandai oleh trombosis di vena dural, yang bisa menyebabkan berbagai gejala termasuk nyeri kepala, kejang, kelemahan motorik, serta penurunan kesadaran. Trombosis juga sering terjadi di ekstremitas bawah pada perempuan postpartum akibat tirah baring lama dan tindakan seksio sesaria (trombosis sistemik yang terjadi pada pasien ini mengarah pada kelainan sistemik/autoimun sehingga diperiksa SLE, jadi diagnosis SLE tidak lebih dahulu diketahui). Cerebral sinus venous thrombosis pada SLE mungkin disebabkan oleh berbagai faktor termasuk vaskulitis dan sindroma antifosfolipid. Pemberian antikoagulan subkutan yang dilanjutkan dengan antikoagulan oral serta mengendalikan SLE dengan kontrol ulang teratur dan pertimbangan pemberian obat-obatan seperti imunosupresan atau hydroxychloroquine (saat laporan kasus ini dibuat pasien telah dikonsultasikan ke bagian penyakit dalam) dan sedang dilakukan follow up dan tata laksana dapat memberikan luaran yang lebih baik pada pasien ini.

\section{DAFTAR PUSTAKA}

1. Rajoor UG, Seema BN. Clinical profile of postpartum cerebral venous thrombosis. Intl J Reprod, Contracept, Obstet Gynecol. 2017;3(1):185-91.

2. Saposnik G, Barinagarrementeria F, Brown RD, Bushnell CD, Cucchiara B, Cushman M, dkk. Diagnosis and management of cerebral venous thrombosis: a statement for healthcare professionals from the American Heart Association/American Stroke Association. Stroke. 2011;42(4):1158-92.

3. Giancal A, Melina V. Epidemiology of cerebral vein and sinus thrombosis. Dalam: Caso V, Angelli G, Paciaroi M. Handbook on cerebral venous thrombosis. Front Neurol Neurosci. Karger; 2008. h. 60-5.

4. Moscote-Salazar L, Alcala-Cerra G, Alvis-Miranda $\mathrm{H}$, Castellar-Leones S. Cerebral sinus venous thrombosis. J Neurosci Rural Pract. 2013;4(4):427.

5. Singh RK, Bhoi SK, Kalita J, Misra UK. Cerebral venous sinus thrombosis presenting feature of systemic lupus erythematosus. J Stroke Cerebrovasc Dis. 2017;26(3):518-22.

6. Wang L, Chen H, Zhang Y, Liu W, Zheng W, Zhang $\mathrm{X}$, dkk. Clinical characteristics of cerebral venous sinus thrombosis in patients with systemic lupus erythematosus: a single-centre experience in China. J Immunol Res. 2015;2015:540738.

7. Bazzan M, Vaccarino A, Marletto F. Systemic lupus erythematosus and thrombosis. Thromb J. 2015;13(1):1-10.

8. Uzun CI. A case of postpartum cerebral venous thrombosis presented by convulsions. Perinat J. 2013;21(2):93-5.

9. Kashkoush AI, Ma H, Agarwal N, Panczykowski D, Tonetti D, Weiner GM, dkk. Cerebral venous sinus thrombosis in pregnancy and puerperium: A pooled, systematic review. J Clin Neurosci. 2017;39:9-15.

10. Liang ZW, Gao WL, Feng LM. Clinical characteristics and prognosis of cerebral venous thrombosis in Chinese women during pregnancy and puerperium. Sci Rep. 2017;7(2):43866.

11. Rossi C, Cardonnier C. Pathophysiology of nontraumatic intracerebral haemorrhage. Dalam: 
Norrving B, Kennard C. Oxford textbook of stroke and cerebrovascular disorder. Oxford: Oxford University Press; 2014. h. 56.

12. Ferro JM, Canhao P. Cerebral venous thrombosis. Dalam: Mohr JP, Wolf PA, Grotta JC, Moskowitz MA, Mayberg M, Kummer R. Stroke pathophysiology, diagnosis and management. Philadelphia: Elsevier; 2011. h. 516-27.

13. Srivastava M, Bhatnagar P, Gupta M. Deep vein thrombosis in post-partum case of caesarean section: a case report. IJSS. 2015;3(1):219-20.

14. Bates SM, Middeldorp S, Rodger M, James AH, Greer I. Guidance for the treatment and prevention of obstetric-associated venous thromboembolism. J Thromb Thrombolysis. 2016;41(1):92-128.

15. Atalay H, Teker F, Boyuk B, Celebi A, Ayar Y, Ekizoglu I. A case of deep vein thrombosis in the postpartum period. J Acad Res Med. 2015;5(1):2830 .

16. Fiengo L, Bucci F, Patrizi G, Giannotti D, Redler A. Postpartum deep vein thrombosis and pulmonary embolism in twin pregnancy: undertaking of clinical symptoms leading to massive complications. Thromb J. 2013;11(1):1.

17. Rasyid A. Peran viskositas darah pada stroke iskemik akut. Neurona. 2014;31(3):1-6.

18. Degirmenci Y, Kececi H, Seker IS. Cerebral sinus venous thrombosis in puerperium: review of the literature in the light of two cases. CMJ. 2015;(3):61-4.
19. Ferro JM, Bousser MG, Canhao P, Coutinho JM, Crassard I, Dentali F, dkk. European Stroke Organization guideline for the diagnosis and treatment of cerebral venous thrombosis-endorsed by the European Academy of Neurology. Eur J Neurol. 2017;24(10):1203-13.

20. Kawaguchi R, Shoji H, Hiroshi K. Venous thromboembolism during pregnancy and postpartum: study in a tertiary hospital. Int J Pregnancy Child Birth. 2016;1(1):1-5.

21. Maria TS, Darulkutni N, Cut AA. Hubungan D-dimer, gula darah dan asam urat dengan volume infark dan keluaran pada stroke iskemik. Neurona. 2014;31(4):1-7.

22. Matsumura Y, Yamamoto Y, Kikuchi I, Takahashi $\mathrm{N}$, Matsuda Y, Saito T, dkk. Early detection of thrombosis after cesarean section using changes in D-dimer levels. Hypertension Res in Pregnancy. 2014;2(1):26-9.

23. Cunha JS, Gilek-Seibert K. Systemic Lupus erythematosus: a review of the clinical approach to diagnosis and update on current targeted therapies. RI Med J. 2016;99(12):23-7.

24. Ropper AH, Samuels MA, Klein JP. Adams and Victor's principles of neurology. Edisi ke-10. New York: MC Graw Hill; 2014. h. 869-71.

25. Alkhouli M, Morad M, Narins CR, Raza F, Bashir $\mathrm{R}$. Inferior vena cava thrombosis. JACC Cardiovasc Interv. 2016;9(7):629-43. 